\title{
The requirement of the law fulfilled in Romans 8:4
}

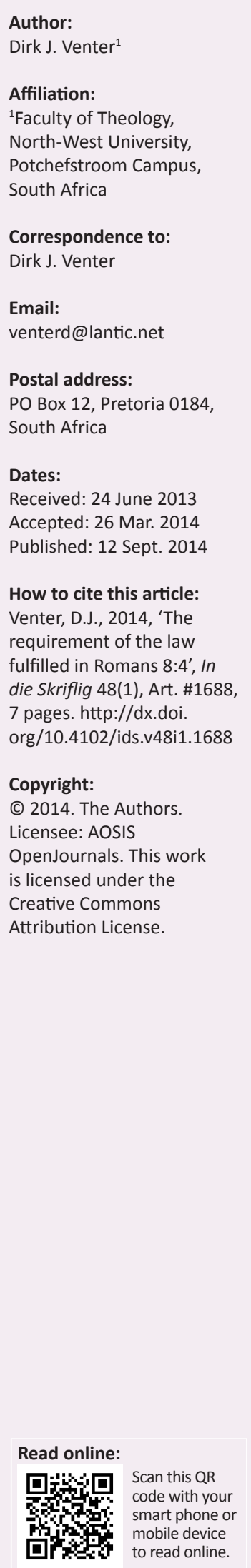

God effects the fulfilment of the requirement of the law through the agency (mission) of Christ. Those 'in him' are the point of reference in whose favour the law's requirement is fulfilled, with the effect that they are no longer obligated to Torah. Being 'in Christ' they, nonetheless, are also envisioned as living in a way that corresponds to what Torah would have required of them, had they still been subject to it, but they are now being governed and empowered by the Spirit. Consequently their lives give expression to the ultimate (singular) requirement and intention $(\delta เ \kappa \alpha i \omega \mu \alpha)$ of Torah. The fulfilment of the requirement of the law refers to the purpose of the law as a whole, and not only of the 'moral' aspect, often anachronistically separated from the 'cultic' aspect. Ultimately, God who originally gave Torah now effected the fulfilment of its intention - something that had been unrealised before the mission of Christ and the gift of the Spirit due to the incapability of the law.

Die vervulling van die wet se vereiste in Romeine 8:4. God bewerk die vervulling van die wet se vereiste $(\delta 1 \kappa \alpha i \omega \mu \alpha)$ deur die bemiddeling van (die sending van) Christus. Dié wat 'in Christus' is, is die begunstigdes van die feit dat die vereiste van die wet vervul is, met die gevolg dat hulle nie meer aan die bepalinge van Tora as sodanig onderhewig is nie. Aangesien hulle 'in Christus' is, word dit egter voorsien dat hulle steeds sodanig sal leef dat dit ooreenstem met wat Tora in beginsel van hulle sou vereis indien hulle steeds daaraan onderhewig was, maar dat hulle dit nou vanweë die heerskappy en bekragtiging van die Gees uitleef. Gevolglik gee hulle lewens gestalte aan die uiteindelike (enkelvoudige) doel en vereiste $(\delta 1 \kappa \alpha i \omega \mu \alpha)$ van Tora. Die vervulling van die wet se vereiste verwys nie na die vervulling van slegs die 'morele' vereistes nie, maar ook na dít wat dikwels op anachronistiese wyse as die 'seremoniële' wet afgesonder word. Uiteindelik het God, wat Tora oorspronklik daargestel het, die vervulling van die wet se bedoeling gerealiseer - iets wat vanweë die onvermoë van die wet ongerealiseerd gebly het in die epog voor die koms van Christus en die gawe van die Gees.

\section{Introduction}

With Romans 8:3-4, Paul addresses the resolution of a threefold problem that stemmed from his argument in Romans 7:7-25. ${ }^{1}$ Through the mission of God's Son, the concomitant problems of (1) sin and (2) the weakness of the flesh are resolved by the condemnation of $\sin$ in the flesh (Rm 8:3). Christ's mission also had the purpose-result of resolving (3) the incapability of the law through the fulfilment of the requirement of the law ( $R m$ 8:4). What this last aspect of the resolution of

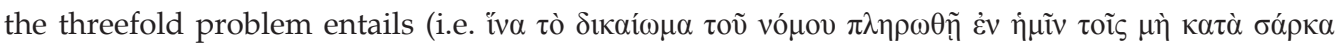
$\pi \varepsilon \rho ı \pi \alpha \tau o \tilde{\sigma} \sigma v \dot{\alpha} \lambda \lambda \grave{\alpha} \kappa \alpha \tau \grave{\alpha} \pi v \varepsilon \tilde{v} \mu \alpha),{ }^{2}$ will be the subject of this article. ${ }^{3}$

Specific questions that arise from Romans 8:4 and its context that will be addressed include:

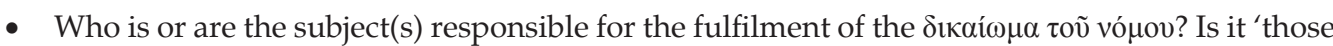
who walk according to the Spirit', the Spirit itself, God, Christ, or are all of the above involved in some way or another?

- If so, then how? Does Torah itself play an enduring positive role in the fulfilment of its own requirement(s)?

- If not, then what has taken over the function of capacitating a life that would be pleasing to God (cf. Rm 8:8)?

1.Romans 8:3-4 should be read as part of Romans 8:1-17, which is antithetically related to Romans 7:7-25 according to the agenda Paul set out in Romans 7:5-6, that is Romans 7:5 is elaborated by Romans 7:7-25, whilst Romans 8:1-17 elaborates upon Romans 7:6 2.All excerpts in Greek are from Black et al. (1997).

3.This article contains edited and reworked material from a paper read at the North-West University's 'God and Cosmology' Conference in August 2012 (South Africa). Recognition is due to Jan van der Watt for his support and input in the preparation of the paper, and to Cilliers Breytenbach, Michael Wolter, Udo Schnelle, Fika van Rensburg and Hermut Löhr for their comments and suggestions towards the improvement of the paper. 


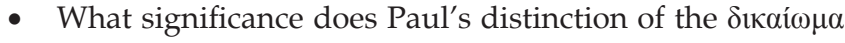

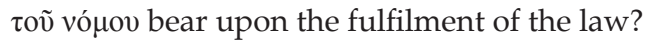

- Does this distinction support the common separation between the 'moral' and 'cultic' requirements of the law, implying that Paul envisioned and Romans 8:4 refers to a partial fulfilment of Torah?

- Lastly, is it not surprising, if not unlikely, that the original purpose of Torah would in the end be met quite apart from Torah?

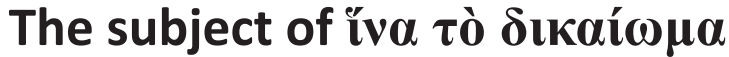

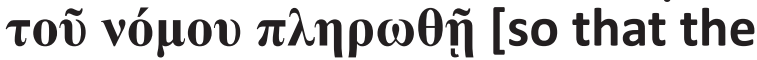 requirement of the law would be fulfilled]}

When iv $\alpha$ indicates 'both the intention and its sure accomplishment' (Wallace 1995:473), often 'in declarations of the divine will' (Bauer et al. [BDAG] 2000:477) - as is the case in Romans 8:3-4 where the condemnation of sin was God's will and action - it is used to express both purpose and result (e.g. Cranfield 1975:383; Bertone 2005:226), that is purposeresult. It was God's purpose when he (negatively) dealt with sin through its condemnation in the flesh that Christ's mission should not only accomplish this, but also (positively)

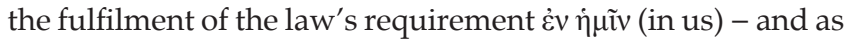
God purposed, so it was.

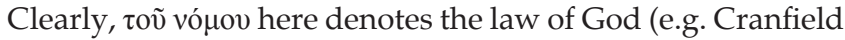
1975:384; Thurén 2000:132; Dunn 2002:423; Bertone 2005:242; Jewett 2006:485), that is Torah, as it did in Romans 8:3 (Schnelle 2005:339-340). Expositors are also generally agreed that $\pi \lambda \eta \rho \omega \theta \tilde{n}$ denotes fulfilment in this context. BDAG (2000:828) defines the appropriate sense of $\pi \lambda \eta \rho$ ó $\omega$ as 'to bring to a designed end, fulfil' as in 'a prophecy, an obligation, a promise, a law', et cetera (cf. Delling 2000:286-298). This may perhaps also be described as 'to complete what was supposed or intended to be done'.

The question, however, is: Who is the subject of $\pi \lambda \eta \rho \omega \theta \tilde{\eta}$ ? or Who fulfils the requirement of the law? Jewett (2006:485) notes that 'Paul retains a barrier against self-salvation' by means of the passive $\pi \lambda \eta \rho \omega \theta \tilde{\eta}$ and its qualifier $\dot{\varepsilon} \nu \dot{\eta} \mu \mathrm{i} v$ (cf. Fee 1994:535; Moo 1996:483-484). Thus the passive is often viewed as a 'theological passive' (Fitzmyer 1993:487), that is that God is the actual subject. ${ }^{4}$ Although the fulfilment of the law's ultimate requirement does somehow involve

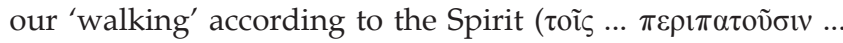
$\kappa \alpha \tau \grave{\alpha} \pi v \varepsilon \tilde{v} \mu \alpha)$, God remains the subject of Romans 8:3-4. It is he who, by means of the mission of his Son, purposed and achieved not only that sin was decisively dealt with (in the flesh), but also that the law's requirement is fulfilled. This fulfilment of the law's requirement does, nonetheless, have

4.Cf. also, in Pauline tradition, 2 Thessalonians 1:11-12, where God is entreated to, as subject, fulfil 'every good resolve and work of faith' so that the Name of Jesus christ may be glonified 'in ' Christ may be glorifed " in you'. These "good resolves' and 'works of faith" obviously are to be accounted to the believers, although it is God who is entreated to fulfil it. This formulation is strikingly similar to Romans $8: 3-4$ in its theological emphasis on God fulfilling that which would otherwise be described as actions of the believers. 'us' as its point of reference ( $\dot{\varepsilon} v \dot{\eta} \mu \tilde{\mathrm{i} v}) .^{5}$ Thus, the fulfilment of the law's requirement is God's action in accordance with his will and initiative - and 'not the striving of believers' (Bertone 2005:227), but our own moral involvement ${ }^{6}$ is also implied as is clear in the $\sigma \alpha \dot{\alpha} \rho \xi-\pi v \varepsilon \tilde{u} \mu \alpha$ [flesh-spirit] antithesis in Romans 8:4-13.

How should this interaction between God's action and our own involvement in the fulfilment of the law in Romans 8:4 be understood? It is God himself who fulfils what the law requires, and contextually it is clear that he does this through the mission of his Son (Schnelle 2005:340). The incapability of the law is just as much the incapability of Adamic man to fulfil the law, because it is man's fleshliness that incapacitates the law, and thus also himself to obey the law. Consequently, God did, through Christ, what the law could not enable man to do: he fulfilled the law's requirement. This can be described in covenantal or contractual terms as Christ, being God's agent, fulfilling those obligations that the Sinai covenant had laid upon God's people. By summarising all of these obligations

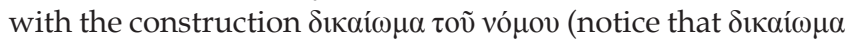
is in the singular), Paul is saying that Jesus' mission - that is his life, in likeness to sinful flesh, and death, whereby sin was condemned - effectively paid the sum of the covenantal obligations of God's people in toto. He already did all that the law required. His subsequent resurrection in which they would come to partake (Rm 8:11) and their reception of Christ's Spirit (Rm 8:9, 15), which testifies to their being God's children (Rm 8:16), would confirm the establishment of the new kind of covenant that was born out of Christ's fulfilment of the covenant requirements.

\section{No longer obligated to Torah, but in step with the Spirit}

This has significant implications for those who are 'in Christ Jesus' (Rm 8:1). In terms of Paul's Adam Christology, Christ having fulfilled everything the law requires means that, by their participation through faith and the application of that which is true of Christ to the lives of the believers by the Spirit, the requirement of the law has already been met with reference to those who are 'in him ${ }^{\prime 7}$ and is consequently

5.Appropriate to the syntax and context of Romans $8: 4$, غ $v$ can denote either agency (by/with, i.e. 'instrumental' in Wallace) or reference and respect (cf. Wallace 1995:372; BDAG 2000:329). Ultimately, expositors' decision, as in this article, to avoid the sense of human agency is based on theological grounds, that is based on Paul's theology as a whole, and not on indications in the immediate text itself. Cf. also Fee (1994.536), who argues for the locative sense: '[W] as his people are the sphere in which God by his Spirit has fulfilled his divine purposes set forth in the sphere in which God by his Spirit has fulfilled his divine purposes set forth in the law' and 'it is in Us, in the believing community [...] that God is fulfilling his purposes.' Cf. Wilckens (1980:128), who already noted the corporate aspect and the syntactical legitimacy of both the instrumental and locative senses.

6.This involvement is described by Paul as a matter of fact when he asserts that we

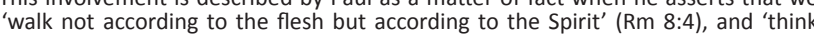
upon that which is of the Spirit' (Rm 8:5). In Romans 8:13 there is an implied exhortation in the form of a conditional clause, namely 'if you put to death the works of the body by the Spirit', preceded by the mention of being indebted to God or the Spirit. Cf. Fee (1994:535-538) and Moo (1996:485): 'Paul does not separate the "fulfilment" of the law from the lifestyle of Christians. But, this does not mean that Christian behavior is how the law is fulfilled.'

7.Wolter (2011:237) describes one significant way (determined by context) in which Paul applies the term in Christ as denoting 'eine prototypische Inklusivität' ['a prototypical inclusivity'], which is in contrast of being 'in Adam'. Paul uses 'in ['a prototypical inclusivity'], which is in contrast of being 'in Adam'. Paul uses 'in Christ' in Romans 8:1 in this way - or alternatively, merely as a way of identifying the group that we would today call 'Christians' (Wolter 2011:241-243). Possibly both interpretations are simultaneously valid for Romans $8: 1$. Be that as it may, these two use 'the way 'in Christ' is used throughout this article. 'Inclusion' and 'participation' in what is true of the prototypical Christ are regarded as synonymous terms. See also Schnelle (2009:321-322). 
no longer applicable to them. ${ }^{8}$ They are freed from their obligation to Torah ( $R m$ 8:2; Wolter 2011:372) through their participation in Christ who, as Godsend Adamic representative of humankind, has already fulfilled the sum of all that Torah requires of God's covenant partners (cf. Rm 5:18-21). This emancipation, from personified sin and from Torah conquered by it, makes sense, since the obligation to Torah had not brought those who wanted to obey it to obedience in any case ( $\mathrm{Rm}$ 7:22-23).

The emancipation from Torah does not, however, lead to a life without bounds (cf. Rm 6:15ff.). The irony is that those 'in Christ' who have no more obligation to Torah will now actually fulfil what Torah would have required of them, had they still been under it. This happens, because the transformative mission of God's Son has transferred them from one sphere of authority to another. ${ }^{9}$ They are no longer subject to Torah, which itself had been conquered by personified sin who reigned in the flesh (Rm 7:13-14, 22-23, $25 \mathrm{~b})$. The sphere of authority where personified sin reigns,

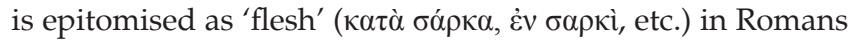
8:4-13. Those 'in Christ', however, have now been placed under the authority of the Spirit of Christ ( $R m$ 8:9), that is

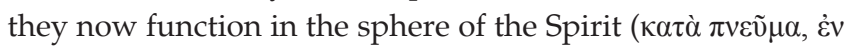
$\pi v \varepsilon v ́ \mu \alpha \tau$, etc.) Their walk according to the Spirit (Rm 8:4) is in continuity with Christ's fulfilment of the law in which they partake. Elsewhere Paul comments that the law has nothing against this kind of walk (Gl 5:16, 23) ${ }^{10}$ Consequently, the 'walk' itself is often interpreted as living in such a way (i.e. according to the Spirit) that one actually meets the 'requirement of the law' (e.g Byrne 1996:244; Cranfield 1975:384; Jewett 2006:485; Fee 1994:535).

The point is that this way of life, which meets the standard of the law, is enabled by the Spirit as opposed to being enabled by Torah itself, which was incapable of effecting the required outcome. An additional point that should not be overlooked, however, is that living in accordance with the Spirit and consequently meeting the standard of the law, is secondary to Christ having first and already fulfilled all that the law required of God's people. Thus, those who partake in Christ's fulfilment of the law now actually do what the law would have required of them - not because they are obligated by the law, but because they are freed and enabled by Christ's Spirit to do so. A contextual reading of Paul's use of $\pi \lambda \eta \rho$ ó $\omega$ confirms this exposition.

8.This explains why Paul does not, as a rule, base his ethical instructions on Torah (Schnelle 2009:323-324), although his quotations from and allusions to the Old Testament proves that he still regarded it as inspired Scripture, particularly in the sense of it being the promise of (Schnelle 2005:325-326) and witness to Christ Where Paul does quote from or allude to Torah in his paraclesis (on why this is a more appropriate term than parenesis, see Schnelle 2009:327), it is in order to concretise and illustrate a general instruction (e.g. to love one's neighbour in Rm 13:8-10) and to illustrate the authoritativeness of the instruction - not to imply that his readers are to (still) orientate themselves towards the precepts of Torah as such. On the consistency of Paul's view of the law, see Schnelle (2005:517-521).

9.The transference from one sphere of authority to another through Christ's mission (particularly his death and resurrection) is simultaneously also transference between 'epochs' (see Dunn 1998:317-319).

10.Even though this is not effected by being 'under the law', but by being led by the Spirit (GI 5:18)

\section{$\Delta$ เкaí $\omega \mu \alpha$ and the fulfilment of the Law - in principle}

Paul uses the verb $\pi \lambda \eta \rho$ ó $\omega 13$ times (Rm 1:29; 8:4; 13:8; 15:13, 14, 19; 2 Cor 7:4; 10:6; Gal 5:14; Phlp 1:11; 2:2; 4:18, 19) in his undisputed epistles - of which explicitly in relation to vó $\mu$ o [law] in Romans 8:4 and 13:8 (cf. also Rm 13:10: $\pi \lambda \eta \dot{\rho} \omega \mu \alpha$ ỡv

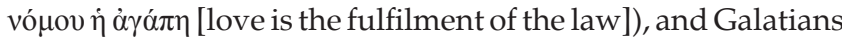
5:14. The last two of these references identify the fulfilment of the law with love for one another or the neighbour. Common to the contexts of both Romans 8:4 and Galatians 5:14 is Paul's insistence that those who are led by the Spirit are no longer under the law (Gl 5:18), but free from it ( $\mathrm{Rm}$ $7: 6 ; 8: 2,12-14)$. Consequently, it can be deduced that behind these texts on the fulfilment of the law lies Paul's conviction that it is possible to fulfil the law in principle without being focused on each and every precept of the law as such, or perhaps without even having the law. ${ }^{11}$ This is confirmed by the context of $\pi \lambda \eta \rho \omega \theta \tilde{\eta}$ in Romans 8:4.

It may be significant that, in this context, Paul does not say (cf. Rosner 2010:411-414) that those who now walk according to the Spirit are fulfilling $(\pi \lambda \eta \rho \omega \theta \tilde{\eta})$ the law as such. What is at stake is the fulfilment of the requirement ( $\tau$ ò $\delta$ เкаi $\omega \mu \alpha)^{12}$ of the law. Note the singular (Cranfield 1975:384): 'requirement'13 and not 'requirements'. ${ }^{14}$ No longer is the keeping of the commandments as such in view, but rather the fulfilment of the ultimate intention (Thurén 2000:132-133) ${ }^{15}$ of those

11.See Bertone (2005:232-241). Cf. also Romans 2:25-29, where the uncircumcised that is Gentile Christians (Gathercole 2002:39), clearly not keeping certain aspects

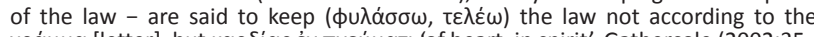

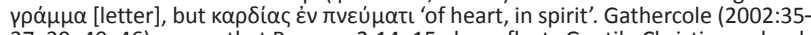
$37,39-40,46)$ argues that Romans 2:14-15 also reflects Gentile Christians who do

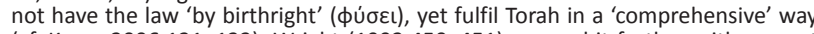
(cf. Kruse 2006:121-123). Wright (1992:450-451) goes a bit further with respect to 1 Corinthians 7:19, arguing that 'to be acting in accordance with the whole divine purpose for Israel, [was] precisely in dismantling those aspects of traditional praxis, and in disregarding those traditional symbols [e.g. circumcision], by which for centuries Jews had ordered their lives'.

12.BDAG (2000:249) defines the appropriate sense of $\delta$ เк $\alpha$ เ $\omega \alpha$ as 'a regulation relating to just or right action, regulation, requirement, commandment' [emphasis original].

13.Ziesler $(1988: 50-51,56)$, noting the significance of the singular form, has argued that $\delta$ icoí $\omega$ u does not refer to the law as a whole in the New Testament or the Septuagint (although he concedes that $\operatorname{Pr} 8: 20$ and 19:28 are possibilities, but 'not strong ones'; cf. however Schrenk 2000:221). He has suggested that the 10th commandment is in view here for the prohibition against coveting also dominated Romans 7:7-25. This proves to be overly restrictive, because the immediate context of Romans 8:4 does not lend support to such an application (Bertone 2005:231). Moreover, the 10th commandment is applied in Romans 7:7-25 precisely to function as a key to or 'paradigm for' (Kruse 2006:126) the rest of the commandments. It is, in that context, the supreme type of the law, so that what is true of it will also be true of every other commandment, and of the law as a whole. As the law against covetousness has ironically led to covetousness, so any other specific commandment would ironically ultimately awaken the desire (exy other specific commandment would ironically ultimately awaken the desire ( $\varepsilon \pi \mathrm{i} \theta v \mu i \alpha)$ to do what that commandment forbids or not to do what it commands. This is why the 10th commandment is so fitting to be the synopsis of Torah in Roman 7:7-25: it typifies the inherent flaw of the law identified by Paul - it ultimately awakens exactly what it forbids ( $\sin$ ). Jewish tradition allowed for covetousness to be the sin from which all others flowed (Ziesler 1988:47). Paul took this one step further and argued that the law itself, because of sin and the flesh, became the actual initiator of the desire to sin. Even more to the point, Paul uses different words (Byrne 1996:244) for 'commandment' in the context of Romans 7:7-25

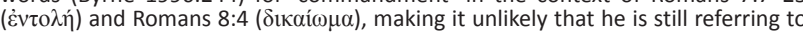
the 10 th commandment as such in Romans 8:4. Rather, the fact that the law could be summarised in one commandment, and often was in Jewish tradition (cf. Rm 13:9; Dunn 2002:778-779), gave Paul the occasion to envision the fulfilment of the intention of the law as a whole with the new term $\delta 1 \kappa \alpha i \omega \mu \alpha$, which is no longe connected to the $\dot{\varepsilon} v \tau 0 \lambda \eta$ against covetousness as such.

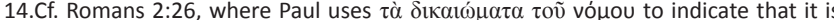
possible for Gentiles to keep the other requirements of the law as opposed to those 'his fellow Jews would normally focus on as part of their distinctive self-definition', for example circumcision, Sabbath, food laws, et cetera. (Dunn 2002:423).

15.Cf. Fitzmyer (1993:487): 'what the law ideally required' and 'the goal or purpose of the law'. 
commandments as a whole (e.g Cranfield (1975:384), ${ }^{16}$ or in essence (Byrne 1996:244; Schnelle 2005:519).$^{17}$ Also important is that the keeping of the commandments as such is no longer the way to fulfil the intention of the law as a whole - any such attempt is thwarted by the law's ultimate incapability because of its inseparability from the weakness of our Adamic fleshliness (Rm 8:3).

The requirement or intended outcome of the law as a

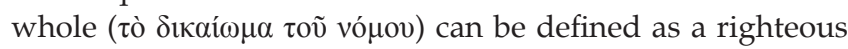
standing before God, which is first and foremost the result of one's inclusion or participation 'in Christ'. The formulation of Romans 8:4, which continues with the ethically laden term $\pi \varepsilon \rho 1 \pi \alpha \tau \varepsilon \dot{\varepsilon} \omega$, [to walk], also signifies, however, that the fulfilment of the requirement of the law implies, and is inseparable from, our righteous living (cf. Fee 1994:530; Byrne 1996:237). From this second perspective, the

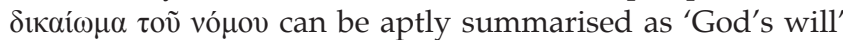
(Käsemann 1980:218). ${ }^{18}$ for his people, which Paul elsewhere himself summarises as 'to love another' (Rm 13:8; Gal 5:14; cf. also Wolter 2011:337-338; Kruse 2006:125-127; Schnelle 2005:323). ${ }^{19}$ One who does God's will by loving his neighbour is fulfilling the ultimate requirement of the law, even though he may have no knowledge of Torah as such. ${ }^{20}$ Consequently, the requirement or intended outcome is still valid, even though keeping the distinct precepts of the law as such is no longer required (cf. Rm 7:1-6; 10:4-10; Kruse 2006:115-129), because it is now primarily the Spirit of Christ that will guide those who believe to 'walk' according to God's will - that is to give concrete expression to the single love commandment.

Dunn (2002:423) criticises 'those who can only see that Paul is trying to maintain an untenable "both and" at this point - the law at an end (10:4) yet still valid' (e.g. Räisänen \& Sanders). It is possible, however, that this 'both and' is not so untenable for Paul because of the distinction he seems to make between keeping the precepts of the law as such and fulfilling, in

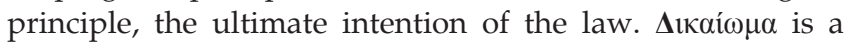
key to this distinction. ${ }^{21} \mathrm{~A}$ particular requirement, purpose

16.Cf. Schrenk (2000:221): "the singular is used again to denote the law in its unity', comparable to its use in Romans 1:32, on which Schrenk comments: 'in Paul's eyes it is important to emphasize that there is for the Gentiles a recognizable divine the one divine will'. Cf. Moo (1996:482): 'the summary of what the law demands of God's people'.

17.Cf. Dunn (2002:423): 'the essential requirement [note again the singular] which lies behind the individual requirements, the character and purpose which the individual requirements are intended to bring to expression'.

18.Jewett (2006:485) also supports this exposition of $\delta$ เкa $\omega \mu \alpha \alpha$ as 'the requirement of the Mosaic Law conceived in its unity', which he 'in the light of the rest of the argument of Romans' equates to 'the fatherly will of God for his children' (cf. Cranfield 1975:384).

19.Löhr (2010:207) describes love as 'the summation and fulfilment of the Law's

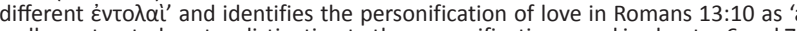
well-constructed contra-distinction to the personifications used in chapter 6 and 7 ', that is particularly sin. Schnelle (2009:322) states that 'in the Pauline ethic, love [... is the goal of every action' [author's italics].

20.In this regard, Schnelle (2005:324) points out (with reference to Paul's allusions to the Old Testament, and to other Jewish sources) that Abraham was seen as fulfilling Torah before Israel had received it, and that Abraham was counted 'righteous', because he did the will of God without knowing or obeying the precepts of Torah as such.

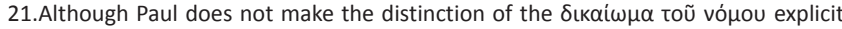
in the context of either Romans 13:8-10 or Galatians 5:14, in both cases he does the coes define the one, ultimate purpose of the law, namely love. On the other hand, in the context prins principle behind all the commandments by using the term $\delta$ ikai $\omega \mu \alpha$. Thus, he is consistent when he speaks of the fulfilment of the law in that it refers to fulfilment of the law as a whole and in principle - not by keeping the commandments as such. or intention, originally associated with a particular means of achieving it, may still be valid, even though the means to achieve it has expired or has been replaced because of its ineffectiveness. Thus, Torah's requirement, purpose or intention is still valid, but itself, as the means by which one can attain that goal, is no longer valid (Fee 1994:536), ${ }^{22}$ having been replaced by the enablement ${ }^{23}$ of the Spirit that is diametrically opposed to the 'incapability of the law in which it was weak through the flesh'. Since the law itself as the means by which this intention can be fulfilled, has been proven 'incapable', the realisation of the law's intention can only be the result of Christ's soteriological mission that transferred those 'in him' from the sphere of sin and death to the sphere of the Spirit - capacitating a walk according to the Spirit (Käsemann 1980):

As he releases us from the dominion of the powers [of sin and death], the Spirit evokes the new obedience and thus establishes the rights of the divine will which had been originally manifested in the law. (p. 218)

\section{The law fulfilled in part only?}

As is not uncommon, Bertone (2005:234) isolates the 'ethical dimensions' of the Law from its 'cultic requirements', ${ }^{24}$ concluding that Paul expects only the former to be fulfilled. Although the intention would seem to be correct, that is Paul does expect moral behaviour that would to a large extent correspond to what the law prescribed, but not that Gentile Christians should observe the 'cultic requirements' of the law (cf. Bertone 2005:230-234), there are, not least in the context of Romans 8:4, notable problems with this distinction, apart from the previously mentioned fact that it is anachronistic (Wolter 2009:468-470) Firstly, it does

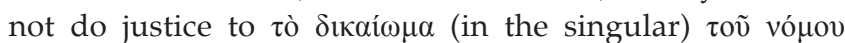
denoting the law as a whole, because it dichotomises the law and only allows for the fulfilment of a part of it. Secondly, this dichotomy begs the question why God instituted these 'cultic' requirements in the first place, namely what their purpose was. Did the 'cultic' and 'moral' aspects of the law

22.Also pertinent here is Paul's insistence in Romans $3: 21-31$ that those who have faith in Jesus Christ is justified ( $\operatorname{Rm} 3: 26$ ) and also vó $\mu$ ov iotóvo $\mu \varepsilon v$ [uphold the law]

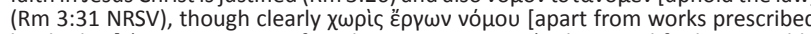
by the law] (Rm 3:28 NRSV; cf. Wolter 2011:351-358). Thus, Paul finds it possible

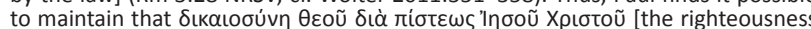
of God through faith in Jesus Christ or the faith of Jesus Christ] (Rm 3:22 NRSV)

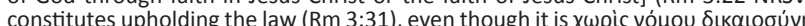
[righteousness apart from the law] (Rm 3:21). Note that Romans 3:21 does not

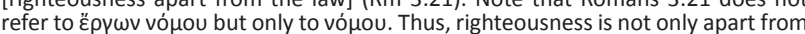
the 'works of the law', but also quite apart from the law as such. In this context,

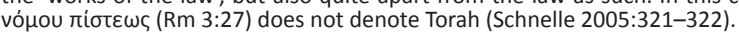

23.The concept of 'enablement' should be used and understood with care. In Romans $8: 4$ itself, Paul is not saying that those who walk according to the Spirit are only enabled to fulfil the requirement of the law, but that this requirement is actually fulfilled through Christ and with reference to them. Such was God's purpose furough the mission of his Son, and such was the result. However, the succeeding through the mission of his Son, and such was the result. However, the succeeding
context makes clear that Paul is also not thinking in automatistic terms. The context makes clear that Paul is also not thinking in automatistic terms. The
fulfilment of the requirement of the law 'in us' involves our 'walking' according to the Spirit (Rm 8:4), 'being' according to the Spirit ( $\mathrm{Rm} \mathrm{8:5),} \mathrm{'thinking'} \mathrm{upon} \mathrm{that}$ which is of the Spirit ( $\mathrm{Rm} 8: 5)$ and 'putting to death' the works of the body by the Spirit (Rm 8:13). Thus, speaking of the Spirit's enablement to fulfil the law's intention is appropriate for the context of Romans 8:4, but keep in mind that in Romans 8:4 proper Paul speaks of the fulfilment of the law's intention in terms of the 'already' rather than the 'not yet' or the 'potential'. Cf. Byrne's (1996:234-241) 'ethical possibility'.

24.Bertone (2005:234) clarifies what he means by 'cultic requirements' as 'circumcision, food regulations, Sabbath day', and, in a note on Eckert, equates

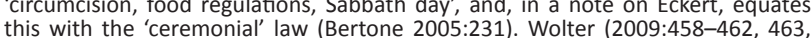
468-469) has shown that this technical distinction between 'ceremonial' and 'moral' law actually only dates from the Latin churchfathers and that reading it 'moral' law actually only dates from the Latin churchfathers and that reading it
into Paul's letters or the literature of any other New Testament author, is an error of anachronism. 
really have distinct purposes? Thirdly, as Bertone's (2005: 230-234) position presupposes, if this is so, the question arises: if the purpose of the 'moral' aspect of the law (i.e. moral living) remained valid, as was shown above, is it not possible that the purpose of the 'cultic' aspect of the law, if indeed separable, also remained valid even though the 'cultic' commandments themselves are no longer required?

As Byrne (2004) stated, the 'cultic' requirements of the law:

... possessed great symbolic power as affirming and demarcating the identity of the Jewish people, living within a vast sea of other cultures frequently hostile to it. Jews did not carefully observe these practices in order to earn salvation, but to maintain, in a sociological sense, their sense of identity and privilege. (p. 246, [author's italics])

Dunn (1998:356) describes circumcision as 'a fundamental identity marker of the people of the covenant', observance of the Sabbath as 'a touchstone of covenant identity and loyalty', and 'the laws of clean and unclean', which includes food regulations, as 'archetypal' in this sense. These observances played a fundamental role in the affirmation of Israel's identity as God's holy people, in the sense of being 'set apart' (e.g. Ex 31:12-17; ${ }^{25}$ Lv 20:22-26). ${ }^{26}$ The 'cultic' requirements especially (not exclusively) demarcated Israel's unique identity. ${ }^{27}$ Yet ultimately, and also in the self-understanding of Second Temple Judaism (cf. Wolter 2009:464-468), the observance of the 'cultic' law cannot be separated from the rest of the law (Wolter 2011:354-355; cf. also Dunn 2006:183) and was also necessary for the maintenance of Israel's relational standing of being righteous ${ }^{28}$ before God. Thus, the purpose of the 'cultic' law is often differentiated as demarcating and affirming Israel's covenant identity. Yet, its ultimate purpose with the rest of the law pertained to the righteousness of Israel as God's chosen people, that is Israel's part of the covenant that Yahweh had made with them in first choosing them as his special people (Dunn 1998:355). Observance of Torah, as a whole, distinguished Israel from the nations.

Naturally, the exclusivist tendency of the law's identity constitutive and affirmative power was a problem for Paul's theology and apostolate to the Gentiles. This was perhaps most visible with reference to, what is often anachronistically described as, the 'cultic' requirements of the law (cf. Wolter 2011:355; Löhr 2003:36). Dunn (1998:354-359) has argued that

25.'You shall keep my Sabbaths, for this is a sign between me and you throughout you generations, given in order that you may know that I, the LORD, sanctify you' (Ex 31:13 NRSV; [author's italics]).

26.' I am the Lord your God; I have separated you from the peoples. You shall therefore make a distinction between the clean animal and the unclean, and between the unclean bird and the clean; you shall not bring abomination on yourselves by animal or by bird or by anything with which the ground teems, which I have set apart for you to hold unclean. You shall be holy to me; for I the LORD am holy, and I have separated you from the other peoples to be mine' (Lv 20:24-26 NRSV; [author's italics]).

27.Consequently, it is often epitomised as being 'boundary markers', for example Löh (2003:36). Wolter (2011:355) aptly clarifies that these laws (with the rest of Torah) actually function as 'boundary marker[s]', pertaining to those outside the group, and as 'identity marker[s]' to those inside the group.

28. Righteousness in the Septuagint 'implies relationship. A man is righteous when he meets certain claims which another has on him in virtue of relationship. Even the righteousness of God is primarily His covenantal rule in fellowship with His people (Schrenk 2000:195).
Paul refers especially, but again, not exclusively, ${ }^{29}$ to these 'cultic' requirements, leading to Judaic exclusivism, when he speaks of the épy $\alpha$ vó $\mu$ ov [works of the law] (e.g. Rm 3:20, 28; Gl 2:16), which, for Paul, is not the basis of being justified - over against faith in Jesus Christ. Whether one ascribes to the 'old' or the 'new' or some other perspective, it is clear to all that Paul understood at least the 'cultic' requirements of the law, so closely related to an exclusivist Judaic self-understanding, to not be transferable to the new era of the Spirit, where God adopted Gentiles into his renewed covenant people on the basis of their faith in Christ and not on the basis of their adhering to the 'cultic' or other requirements of the law.

That is not to say, however, that the identity of the Pauline communities of faith was not becoming demarcated or 'exclusivist' in their own way (cf. Dunn 2006:324-325). The important difference is that the demarcation of identity boundaries (who is 'in' and who is 'out'; cf. Wills 2008:167-189) would no longer be along the lines of nationality and Torahobservance. Whether 'Jew' or 'Greek' (Rm 1:16; 2:9-10; 10:12), the gospel is 'the power of God for salvation to everyone who has faith' (Rm 1:16 NRSV; cf. Wolter 2011:110). The new demarcation lines defining the identity of the redefined 'righteous' would be, for example, 'faith' (Rm 1:16; 4:5; 10:4; 11:20), belonging to the group who is 'in Christ' (Rm 3:24; 8:1; 12:5; 16:7; etc.), and 'in the Spirit' (Rm 8:9; arguably also Rm 2:29 and 15:16 etc.; cf. Wills 2008:183-188). The difference, to be sure, is that the identity of the Pauline communities of faith is no longer determined by their being God's ethnically based, Torah-abiding, covenant people, but by them being his Spirit-led adopted children (Rm 8:1, 2, 14-16) based on the ethnically inclusive promise to Abraham (see Wolter 2011:356-357), appropriated through faith in Christ (Rm 3:21-4:25). Paul did not dispute the fact that some would be 'in' and some would be 'out' of the group of God's people. ${ }^{30}$ He did, however, dispute the basis of a valid demarcation. The 'cultic' requirements of Torah, which typically and most obviously excluded those whom God, by his Spirit, has clearly included (i.e. Gentile Christians; cf. Ac 10) or would force them to base their religious identity on something (i.e. Torah) other than their relation to Christ, could no longer be valid. The purpose or function of identity demarcation or affirmation, however, would still be valid - only replaced by other, that is Christ-oriented, delineators.

It is in this sense that the requirement of the law as a whole - both the so-called 'moral' and 'cultic' aspects of which the last may particularly have been associated with the unique identity of Israel - is fulfilled with reference to those who not only 'walk according to the Spirit', but could also define their identity as being (see Schnelle 2009:319-322) 'according to the Spirit' (Rm 8:5), being 'in Christ' (Rm 8:1), et cetera.

29.Dunn (1998:358) points out that he is often misunderstood on this point. He does not "claim that "works of the law" denote only circumcision, food laws, and Sabbath', but that 'these where particular focal or crisis points for (and demonstrations of) a generally nomistic attitude'.

30.Cf. Paul's image of the olive tree in Romans 11:16-24, where it is clear, from Paul's perspective, that faith is the basis ( $R m$ 11:20) upon which the Gentiles became perspective, that faith is the basis (Rm 11:20) upon which the Gentiles became
part of God's covenant with Israel, and unbelief is the reason why the greater part of ethnic Israel lost their position within the covenant. Should they not persist in of ethnic Israel lost their position within the covenant. Should they not persist in
unbelief, those who are currently 'out', will once more be grafted 'in' ( $R m$ 11:23), unbelief, those who are curren
where they actually belong. 
Ultimately, the point is that as much as Paul does not expect his readers to keep the so-called 'cultic' commandments of the law, he does not expect them to keep the other commandments either. The requirement of the law is fulfilled not by keeping any of the commandments of the law, but, in terms of Romans 8, by their participation 'in Christ' ( and their 'walking according to the Spirit' (Rm 8:4). It implies

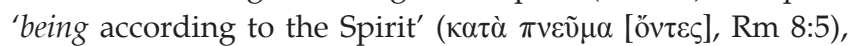
'thinking upon that which is of the Spirit' (Rm 8:6), 'putting to death the works of the body by the Spirit' (Rm 8:13) and being 'led by the Spirit' (Rm 8:14). Along with their Christorientation, ${ }^{31}$ it is particularly the Spirit that determines the identity and the morality of Paul's readers ${ }^{32}$ - neither the 'cultic' nor the 'moral' aspects of the law are determinative anymore. This goes to show that, with regard to Pauline literature, the distinction between the 'cultic' and 'moral' aspects of Torah is not only anachronistic and extraneous (Wolter 2009:455, 468-470), but its relevance is often also dubious. Consequently, it is appropriate to conclude that the Spirit displaces the law (cf. Bertone 2005:171-206, 267-269) ${ }^{33}-$ both as the regulating and the identity constitutive authority in the lives of those 'in Christ'.

\section{The same subject achieving the same goal, but by a new, effective means}

The fact that the requirement, purpose or intention of the law is nonetheless fulfilled with reference to those who live within the authority sphere of the Spirit, namely without any obligation to the law itself (cf. Horn 1992:279-280; Kruse 2006:115-130), should not surprise us. It is, after all, God who originally gave the law - who now also sent his Son, from whose redemptive work emanated the Spirit's sphere of authority in which Paul's communities of faith find themselves. God is the guarantor of the fulfilment of the law's original intention, albeit no longer by the observation of the law itself, but by Christ's redemptive work and the Spirit's empowerment and guidance. Although the law was unable to fulfil its own vision, the comprehensive vision itself that originated with God has not expired. It is only the law in its entirety as the means by which the vision can be accomplished that has expired unequivocally. It is within the parameters of

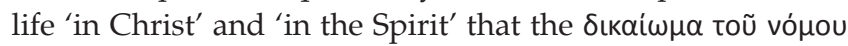
is fulfilled. This happens quite 'apart from the law' (cf. Rm 3:21-31; Wolter 2011:351-358) - that is without an orientation to the commandments of the law as such - of which those 'in

31.'Es geht Paulus vielmehr ganz dezidiert stets um das ganze Gesetz [...] das für Christen in seine Erfüllung durch die Befolgung des Liebesgebots hinein aufgehoben wird [...] Das als 'Gesetz Christi' verstandene Liebesgebot ist für ihn eben nicht durch die Tora, sondern allein durch die stellvertretende Lebenshingabe Jesu Christi normiert' ['For Paul it is decidedly still about the law as a whole [...] which is offset for the Christian, because it is fulfilled by the Christian following the love commandment within [...] The normativity of the love commandment, understoo life as substitution'] (Wolter 2009:469).

32.Schnelle (2009:324) even states: 'The norm of the new being is exclusively the Spirit, who explicitly appears in [G/] 5:18 as the contrast to the Torah' (cf. Löhr Spirit, who
(2007:180).

33. From the soteriological rather than ethical perspective it is also appropriate to speak of the theological disenabling (Depotenzierung) of the law because of (the primacy of) faith (Wolter 2011:359ff.)
Christ' have been discharged ( $\mathrm{Rm} 7: 1-6)$, and which reaches

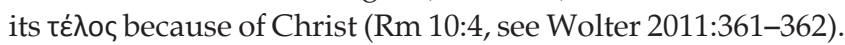

\section{Conclusion}

Concomitant to the problems of sin and the weakness of the flesh was the problem of the law's incapability, that is of bringing about the obedience of God's people (cf. Rm 7:7-25). However, God addressed all three of these problems by means of the mission of Christ - with the purpose-result of the fulfilment of the requirement of the law. As implied subject of $\pi \lambda \eta \rho \omega \theta \tilde{n}$, it is God who effects the fulfilment of the law, and he achieves this through the agency (mission) of Christ. Those 'in him' are the point of reference in whose favour the law's requirement is fulfilled, with the effect that they are no longer obligated to Torah. Being 'in Christ' (who fulfilled all that the law required) they, nonetheless, are also envisioned as living in a way that corresponds to what Torah would have required of them, had they still been subject to it. The fact is, however, that they are now no longer governed and empowered by Torah, but by the Spirit, who applies to their lives all that has been achieved for them by Christ. Consequently, their lives are not orientated toward the fulfilment of the precepts of Torah as such, but nevertheless give expression to the ultimate (singular) requirement and intention $(\delta 1 \kappa \alpha i \omega \mu \alpha)$ of Torah. Distinguishing between the 'moral' and 'cultic' requirements of the law is not valid with regard to Pauline literature in general, or in the context of Romans 8:4 specifically. However, even where this anachronistic distinction is made, it can be argued that the fulfilment of the requirement of the law refers not only to the 'moral' aspect, but also to the 'cultic' aspect of the law (exemplifying the 'boundary markers' between who is 'in' and who is 'out') - supplanting identity based upon Judaic rituals with Christ-orientated delineators such as faith, et cetera. Ultimately, God, who originally gave Torah, now effected the fulfilment of its intention - something that had been unrealised before the mission of Christ and the gift of the Spirit due to the incapability of the law.

\section{Acknowledgements Competing interests}

The author declares that he has no financial or personal relationship(s) that may have inappropriately influenced him in writing this article.

\section{References}

Bauer, W., Danker, F.W., Arndt, W.F. \& Gingrich, F.W. (eds.), 2000, A Greek-English Lexicon of the New Testament and other early Christian literature, 3rd edn. University of Chicago Press, Chicago. (Electronic edn., Logos Bible Software [= BDAG]).

Bertone, J.A., 2005, 'The Law and the Spirit': Experience of the Spirit and displacement of the Law in Romans 8:1-16', Peter Lang Publishing, New York. (Studies in Biblical Literature 86).

Black, M., Martini, C.M., Metzger, B.M. \& Wikgren, A., 1997, The Greek New Testament, United Bible Societies, Federal Republic of Germany. (Electronic edn. Logos Bible Software).

Byrne, B., 1996, Romans, Liturgical Press, Collegeville.

Byrne, B., 2004, 'Interpreting Romans: The new perspective and beyond', Interpretation 58, 241-252. http://dx.doi.org/10.1177/002096430405800303

Cranfield, C.E.B., 1975, A critical and exegetical commentary on the epistle to the Romans, T\&T Clark, Edinburgh. 
Delling, G., 2000, ' $\pi \lambda \eta$ pó $\omega$ ', in G. Kittel \& G. Friedrich (eds.), Theological Dictionary of the New Testament, transl. G.W. Bromiley, vol. 6, pp. 286-298. Eerdmans, Grand Rapids. (Electronic edn., Logos Bible Software).

Dunn, J.D.G., 1998, The theology of Paul the Apostle, Eerdmans, Grand Rapids.

Dunn, J.D.G., 2002, Romans, Word Incorporated, Dallas. (Electronic edn., Logos Bible Software).

Dunn, J.D.G., 2006, The partings of the ways: Between Christianity and Judaism and their significance for the character of Christianity, 2nd edn., SCM Press, London.

Fee, G.D., 1994, God's empowering presence: The Holy Spirit in the letters of Paul, Hendrickson, Peabody.

Fitzmyer, J.A., 1993, Romans: A new translation with introduction and commentary, Doubleday, New York.

Gathercole, S.J., 2002, 'A law unto themselves: The Gentiles in Romans 2.14-15 revisited', Journal for the Study of the New Testament 85, 27-49. http://dx.doi. org/10.1177/0142064X0202400302

Horn, F.W., 1992, Das Angeld des Geistes: Studien zur paulinischen Pneumatologie, Vandenhoeck \& Ruprecht, Göttingen

Jewett, R., 2006, Romans: A commentary, Fortress, Minneapolis.

Käsemann, E., 1980, Commentary on Romans, transl. G.W. Bromiley, SCM Press, London.

Kruse, C.G., 2006, 'Paul, the Law and the Spirit', in S.E. Porter (ed.), Paul and his theology, pp. 109-130, Brill, Leiden.

Löhr, H., 2003, 'Speisenfrage und Tora im Judentum des Zweiten Tempels und im entstehenden Christentum', Zeitschrift für die neutestamentliche Wissenschaf und die Kunde der älteren Kirche 94(1-2), 17-37. http://dx.doi.org/10.1515/ zntw.2003.003

Löhr, H., 2007, 'Paulus und der Wille zur Tat: Beobachtungen zu einer frühchristlichen Theologie als Anweisung zur Lebenskunst', Zeitschrift für die neutestamentliche Wissenschaft und die Kunde der älteren Kirche 98(3-4), 165-188.
Löhr, H., 2010, 'The exposition of moral rules and principles in Pauline letters: Preliminary observations on moral language in earliest Christianity', in R. Zimmermann \& J.G. van der Watt (eds.), Moral language in the New Testament, pp. 197-211, Mohr Siebeck, Tübingen.

Moo, D.J., 1996, The Epistle to the Romans, Eerdmans, Grand Rapids.

Rosner, B.S., 2010, 'Paul and the Law: What he does not say', Journal for the Study of the New Testament 32(4), 405-419. http://dx.doi.org/10.1177/0142064X10366366

Schnelle, U., 2005, Apostle Paul: His life and theology, transl. M.E. Boring, Baker Academic, Grand Rapids.

Schnelle, U., 2009, Theology of the New Testament, transl. M.E. Boring, Baker Academic, Grand Rapids.

Schrenk, G., 2000, ' $\delta$ เк $\alpha i \omega \mu \alpha$ ', in G. Kittel \& G. Friedrich (eds.), Theological Dictionary of the New Testament, transl. G.W. Bromiley, vol. 2, pp. 219-224, Eerdmans, Grand Rapids. (Electronic edn., Logos Bible Software).

Thurén, L., 2000, Derhetorizing Paul: A dynamic perspective on Pauline theology and the Law, Mohr Siebeck, Tübingen.

Wallace, D.B., 1995, Greek grammar beyond the basics: An exegetical syntax of the New Testament, Zondervan, Grand Rapids.

Wilckens, U., 1980, Der Brief an Die Römer, Benziger, Zürich.

Wills, L.M., 2008, Not God's people: Insiders and outsiders in the Biblical World, Rowman \& Littlefield, Lanham.

Wolter, M., 2009, '"Zeremonialgesetz" vs. "Sittengesetz": Eine Spurensuche', in M. Wolter (ed.), Theologie und Ethos im frühen Christentum: Studien zu Jesus, Paulus und Lukas, pp. 453-470, Mohr Siebeck, Tübingen.

Wolter, M., 2011, Paulus: Ein Grundriss seiner Theologie, Neukirchener Verlagsgesellschaf, Neukirchen-Vluyn.

Wright, N.T., 1992, The New Testament and the people of God, Fortress, Minneapolis.

Ziesler, J.A., 1988, 'The role of the tenth commandment in Romans 7', Journal for the Study of the New Testament 33, 41-56. http://dx.doi. org/10.1177/0142064X8801003303 